\title{
Comprehensive effects of supplemented essential amino acids in patients with severe COPD and sarcopenia
}

\author{
R.W. Dal Negro1,2, R. Aquilani3, S. Bertacco1, F. Boschi4, \\ C. Micheletto ${ }^{1}, \mathrm{~S}$. Tognella 1
}

\begin{abstract}
Comprehensive effects of supplemented essential amino acids in patients with severe COPD and sarcopenia. R.W. Dal Negro, R. Aquilani, S. Bertacco, F. Boschi, C. Micheletto, S. Tognella.

Aim. Aim of the study was to investigate whether or not oral supplementation of essential amino acids (EAAs) may improve body composition, muscle metabolism, physical activity, cognitive function, and health status in a population of subjects with severe chronic obstructive pulmonary disease (COPD) and sarcopenia.

Methods. Thirty-two patients (25 males) $\left(\mathrm{FEV}_{\mathbf{1}} / \mathrm{FVC}\right.$ $<40 \%$ predicted), age $75 \pm 7$ years, were randomised $(n=16$ in both groups) to receive $4 \mathrm{gr} / \mathrm{bid}$ EAAs or placebo according to a double-blind design. When entered the study $\left(T_{0}\right)$, after four $\left(T_{4}\right)$, and after twelve $\left(T_{12}\right)$ weeks of treatments, body weight, fat free-mass (FFM), plasma lactate concentration $(\mu \mathrm{mol} / \mathrm{l})$, arterial $\mathrm{PaCO}_{2}$ and $\mathrm{PaO}_{2}$, physical activity ( ${ }^{\circ}$ steps/day), cognitive function (Mini Mental
\end{abstract}

State Examination; MMSE), health status (St.George's Respiratory Questionnaire; SGRQ) were measured.

Results. EAAs supplemented, but not patients assuming placebo, progressively improved all baseline variables overtime. In particular, at $T_{12}$ of EAAs supplementation, body weight $(\mathrm{BW})$ increased by $6 \mathrm{Kg}(p=0.002)$, FFM by $3.6 \mathrm{Kg}$ $(p=0.05)$, plasma lactate decreased from $1.6 \mu \mathrm{mol} / \mathrm{l}$ to $1.3 \mu \mathrm{mol} / \mathrm{l}$ $(\mathrm{p}=0.023), \mathrm{PaO}_{2}$ increased by $4.6 \mathrm{mmHg}(p=0.01)$, physical activity increased by $80 \%(p=0.01)$. Moreover, the score for cognitive dysfunction improved from 19.1 scores to $20.8(p=0.011$, while the SRGQ score also improved from 72.3 to 69.6 even though this trend did not reach the statistical significance.

Conclusions. A three-month EAAs supplementation may have comprehensive effects on nutritional status; muscle energy metabolism; blood oxygen tension, physical autonomy; cognitive function, and perception of health status in patients with severe COPD and secondary sarcopenia. Monaldi Arch Chest Dis 2010; 73: 1, 25-33.

Keywords: Essential Amino Acids supplementation, Sarcopenia, COPD.

1 U.O.C. di Pneumologia, ULSS22 Regione Veneto, Ospedale Orlandi, Bussolengo, Verona,

2 Centro Nazionale Studi di Farmacoeconomia e Farmacoepidemiologia Respiratoria, Verona,

3 Metabolic Service and Nutritional Pathophysiology, Salvatore Maugeri Foundation, Montescano, Pavia,

4 Department of Experimental \& Applied Pharmacology, University of Pavia, Pavia, Italy.

Correspondence: Dal Negro Roberto W., U.O.C.di Pneumologia, ULSS22 Regione Veneto, Ospedale Orlandi, Bussolengo (Verona), Italy; e-mail:rdalnegro@ulss22.ven.it

\section{Introduction}

Chronic obstructive pulmonary disease (COPD) is often associated with substantial weight loss and reduced skeletal mass and function [1-3]. The prevalence becoming underweight is $35-60 \%$ of patients with moderate-to-severe COPD whereas muscle wasting occurs in $20 \%$ of stable COPD [1,4-5].

Weight loss and muscle wasting contribute to a reduction in physical performance and can lead to disability [6]. In advanced COPD, the loss of body weight and the deterioration of muscle mass/function represent independent predictors of morbidity and mortality [7-9]. Furthermore, cachexia, the extreme form of 'underweight' (usually defined by a lean body mass index (LBMI) $<16 \mathrm{Kg} / \mathrm{m}^{2}$ in males and $<15 \mathrm{Kg} / \mathrm{m}^{2}$ in females) [10], reduces the survival rate by half after adjustments for spirometric severity of COPD [10].
Consequently, therapeutic strategies aimed at reversing this particular outcome are of great interest in terms of both patient's prognosis and quality of life. To date, this topic has been adopted by nutritional interventions; pharmacotherapies, and physical training, even though all these options are still proving to have significant limits.

Studies carried out on adding nutritional supplementation to an eight-week integrated pulmonary rehabilitation showed a significant improvement of body weight (BW) associated with a longer survival [11]; an increased fat free mass (FFM); maximal inspiratory pressure; handgrip strength, exercise capacity [12] in a proportion of patients investigated. Conversely, a larger population of patients do not show any benefit from an intensive, integrated, long-term rehabilitation.

Interventional studies that have looked at newer pharmacological approaches (such as: anti-in- 
flammatory drugs [13]; growth hormone [14]; anabolic steroids [15-17]) showed no or negligible benefits on lean body mass, and no significant improvement in lung function.

Whole body physical training, a further support to COPD treatment, was found to induce an anabolic response and an increase of BW by increasing FFM [18]; nevertheless, weight-losing patients are unable to perform an intensive physical having aimed at improving FFM. In addition, low FFM is not the only factor involved in reduced aerobic capacity [19] as reduced peripheral blood flow; impaired energy metabolism with increased rate of anaerobic metabolism, and lactate production may play a further relevant role [20].

In the present study we hypothesised that those limitations could be overcome by a supplementation of simple nutritional substrates, such as essential amino acids (EAAs). By our suggestion, the effects of EAAs on patient with COPD could partially surrogate (or contribute to) the effects of a long-term, intensive, integrated rehabilitation [12]. Actually, EAAs could improve body weight and FFM; peripheral muscle energy metabolism, and exercise capacity. The rationale of using EAAs derives from studies documenting the role of amino acids in regulating protein synthesis [21]; enhancing aerobic metabolism [22], and biological activities of anabolic hormones such as insulin and insulin-like growth factor-1 (IGF-1) [23, 24]. We also formulated a second hypothesis, that EAAs could improve per se the deterioration of both cognitive dysfunction and health status perception [25], which are highly prevalent in COPD [26]. This hypothesis is mainly based on the biological property of several amino acids to act as precursor of brain neurotransmitters [27] involved in cognition, motor function, mood.

\section{Methods}

Thirty-two consecutive out-patients (twentyseven males) suffering from stable severe COPD (GOLD class 3-4) complicated with sarcopenia and to be tested for cognitive dysfunction were recruited and randomly assigned to EEAs (Aminotrofic, Professional Dietetics, Milan, Italy) $4 \mathrm{~g}$ b.i.d. or indistinguishable placebo for twelve weeks according to a double-blind design.

Inclusion criteria were: age $>40$ years; baseline post-brochodilator $\mathrm{FEV}_{1} \leq 50 \%$ predicted; $\mathrm{FEV}_{1}$ / FVC $\leq 70 \%$; BMI score $\leq 23$.

Exclusion criteria were: age $\leq 40$ years; baseline post-bronchodilator $\mathrm{FEV}_{1}>50 \%$ predicted; $\mathrm{FEV}_{1} / \mathrm{FVC}>70 \% ; \mathrm{FEV}_{1}$ reversibility $>12 \%$ from baseline after salbutamol $400 \mathrm{mcg}$; BMI score $\geq 23$; bronchial asthma; diffuse interstitial pulmonary diseases; the presence of any neoplasm; a life expectancy $<1$ year; any mental deterioration severely affecting the adherence to protocol procedures and treatment assumption; lack of minimal autonomy. Patients suffering from acute exacerbation of COPD in the last four weeks were also excluded. All subjects gave their written informed consent to the study.
Patients were checked in baseline $\left(\mathrm{T}_{0}\right)$; after four $\left(\mathrm{T}_{4}\right)$, and after twelve $\left(\mathrm{T}_{12}\right)$ weeks of treatment. Variables collected at all the experimental times were:

- $\quad \mathrm{FEV}_{1}$ and FVC (measured in liters and \% predicted), and $\mathrm{FEV}_{1} / \mathrm{FVC}(\%)$ (Masterscreen Body Jaeger/Carefusion, Hoechberg, Germany);

- $\mathrm{PaO}_{2}$ and $\mathrm{PaCO}_{2}(\mathrm{mmHg}) ; \mathrm{HbO}_{2}$, and lactate $(\mathrm{mmol} / \mathrm{l})$ in arterial blood samples drawn anaerobically from the left radial artery (ABL 735 Analyzer, Radiometer, Copenhagen, DK);

- BMI and the fat free mass (FFM, Kg) via impedentiometric body composition analysis (Tanita BC-420 MA; Tanita Corp., Tokyo, Japan);

- total protein and albumin concentration $(\mathrm{g} / \mathrm{l})$ in blood;

- $\quad$ the dyspnoea score (MRC scale);

- the Mini Mental Questionnaire score;

- Quality of Life assessed in baseline and at the end of both the twelve-week treatments by the St. George Respiratory Questionnaire (SGRQ);

- total number steps were measured daily at home during patients' free-living by the SenseWear Armband PRO3 (BodyMedia; Pittsburgh, PA, USA), continuously worn by the patients for one week in baseline, and during each fourth week of both treatments.

In baseline, lung function was also preliminary assessed before and thirty minutes after salbutamol $400 \mathrm{mcg}$ in order to check the patients' short-term reversibility (\% change $\mathrm{FEV}_{1}$ from baseline).

\section{Statistics}

Descriptive statistics (mean \pm standard deviation) were reported for all the analysed variables. Baseline characteristics of the EAAs supplemented group vs. placebo were compared by means of a Student's $t$ test for unpaired data. A repeated measures analysis of variance model with one factor (Group) was applied to evaluate trends over time for all the collected variables. Statistical significance was expressed as the value of the time* Group interaction, testing the different trends between patients belonging to the placebo or treated group. The Bonferroni posthoc test was also used to check any difference among different time points within and between curves. As significance level of $p<0.05$ has been accepted.

\section{Results}

\section{Patients' characteristics in baseline}

After randomisation, the two groups of sarcopenic COPD patients were well matched in terms of baseline lung function; body weight and body composition; skeletal muscle metabolism; physical activity; cognitive dysfunction, and altered perception of their health status (table 1).

Both groups of patients were also comparable in terms of increased plasma lactic acid levels, 


\begin{tabular}{|c|c|c|c|c|}
\hline Variables & nv & Placebo group & EAA supplemented group & $p$ value \\
\hline \multicolumn{5}{|l|}{ Demographic } \\
\hline Male/Female & - & $11 / 5$ & $14 / 2$ & - \\
\hline Age (years) & - & $75 \pm 7$ & $75 \pm 7$ & - \\
\hline \multicolumn{5}{|l|}{ Anthropometric } \\
\hline BW $(\mathrm{Kg})$ & - & $54.38 \pm 7$ & $53.75 \pm 6.4$ & 0.8 \\
\hline BMI $\left(\mathrm{Kg} / \mathrm{m}^{2}\right)$ & - & $20.2 \pm 1.8$ & $20.2 \pm 1.4$ & 0.97 \\
\hline LBMI $\left(\mathrm{Kg} / \mathrm{m}^{2}\right)$ & - & $14.92 \pm 2$ & $15.3 \pm 1.94$ & 0.58 \\
\hline \multicolumn{5}{|l|}{ Body composition } \\
\hline FFM $(\mathrm{Kg})$ & - & $39.86 \pm 4.8$ & $40.46 \pm 3.8$ & 0.70 \\
\hline $\mathrm{FM}(\mathrm{Kg})$ & - & $14.52 \pm 2.3$ & $13.29 \pm 2.6$ & 0.8 \\
\hline \multicolumn{5}{|l|}{ Serum protein } \\
\hline Total proteins $(\mathrm{g} / \mathrm{l})$ & $65-80$ & $61.57 \pm 5.15$ & $61.7 \pm 3.2$ & 0.93 \\
\hline Albumin $(\mathrm{g} / \mathrm{l})$ & $35-50$ & $33.16 \pm 2.7$ & $32.94 \pm 3.7$ & 0.68 \\
\hline \multicolumn{5}{|l|}{ Pulmonary function } \\
\hline $\mathrm{FEV}_{1}(1 / \mathrm{sec})$ & - & $0.84 \pm 0.15$ & $0.90 \pm 0.21$ & 0.34 \\
\hline $\mathrm{FEV}_{1} / \mathrm{FVC}(\%)$ & - & $38 \pm 11.5$ & $39 \pm 7.18$ & 0.58 \\
\hline \multicolumn{5}{|l|}{ Blood gas tension } \\
\hline $\mathrm{PaO}_{2}(\mathrm{mmHg})$ & $80-100$ & $60.15 \pm 4.88$ & $61.285 \pm 8.3$ & 0.64 \\
\hline $\mathrm{PaCO}_{2}(\mathrm{mmHg})$ & $35-45$ & $46.28 \pm 7.6$ & $45 \pm 6$ & 0.61 \\
\hline \multicolumn{5}{|l|}{ Oxygen saturation } \\
\hline $\mathrm{HbO}_{2}(\%)$ & - & $94.32 \pm 0.96$ & $94.38 \pm 2$ & 0.91 \\
\hline \multicolumn{5}{|l|}{ Muscle metabolism } \\
\hline Plasma lactate $(\mu \mathrm{mol} / \mathrm{l})$ & $-0.5+0.5$ & $1.73 \pm 0.27$ & $1.63 \pm 0.68$ & 0.62 \\
\hline \multicolumn{5}{|l|}{ Daily walking } \\
\hline Steps $\left(\mathrm{n}^{\circ}\right)$ & - & $609.81 \pm 454.72$ & $602.25 \pm 655.86$ & 0.97 \\
\hline \multicolumn{5}{|l|}{ Cognitive function } \\
\hline MMSE (score) & $\geq 24$ & $20.19 \pm 3.52$ & $19.12 \pm 4.6$ & 0.47 \\
\hline \multicolumn{5}{|l|}{ Health status } \\
\hline SGRQ (score) & - & $71.44 \pm 6.98$ & $72.25 \pm 8.52$ & 0.77 \\
\hline
\end{tabular}

Data is expressed as main \pm standard deviation $(\mathrm{SD})$.

Statistical analysis: Student's t test for unpaired data; placebo group vs EAA supplemented group.

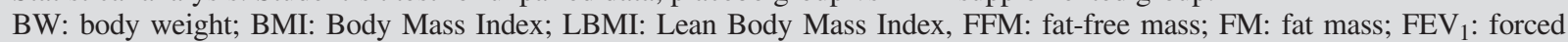
expiratory volume in one second; $\mathrm{FVC}$ : forced vital capacity, $\mathrm{PaO}_{2}$ : partial pressure of oxygen; $\mathrm{PaCO}_{2}$ : Partial pressure of carbon dioxide; $\mathrm{HbO}_{2}$ : oxygen saturation; MMSE: Mini Mental State Examination test; SGRQ: St.George's Respiratory Questionnaire. nv: normal value.

with an average value 5-fold the upper limit for our laboratory, thus indicating the prevalence of a glucose anaerobic metabolism within their muscle tissue, and suggesting the existence of a cell energy storage. Their similarity in body weight and fat free mass was expected since patients were selected for being sarcopenic. To note that all patients were characterised by a substantial reduction of their physical activity, being the total number of steps just about 600 daily.

Patients also showed a reduction in liver protein synthesis of comparable extent as indicated by a serum albumin concentration lower than $35 \mathrm{~g} / \mathrm{l}$. Furthermore, their cognitive status proved equally mildly deteriorated as suggested by the Mini Men- tal State Examination Test (MMSE), with a basal score of 19 in the placebo and 20 in the EAAs group, respectively. Finally, all patients perceived their health status and quality life as very poor.

Of the correlations carried out among all variables (such as: lung function; nutritional status; muscle metabolism; physical activity; cognitive dysfunction, and health status perception), only lactate and physical activity were significantly correlated $(\mathrm{r}=-0.35, p<0.05)$. In other words, sarcopenic COPD patients with cognitive dysfunction enrolled in the study were characterised by a pathological blood gas tensions; muscle metabolism, physical activity, and protein synthesis in basal conditions. 


\section{Patients' characteristics after intervention}

The time courses of variables obtained after placebo or EAAs supplementation showed that patients assuming EAAs, but not those assuming placebo, progressively improved their nutritional status; muscle metabolism; oxemia, daily physical activity; cognitive capacity, and perception of health status (table 2, figure 1 ).

At the end of the study $\left(\mathrm{T}_{12}\right)$, a substantial EAAs-associated increase in both body weight $(+6$ $\mathrm{Kg},+11 \%)$ and FFM $(+3.6 \mathrm{Kg} ;+8.9 \%)$; a drop in lactate plasma levels (from $1.6 \pm 0.7 \mu \mathrm{mol} / 1$ to $1.3 \pm 0.6 \mu \mathrm{mol} / \mathrm{l})$ was also observed, even if the corresponding absolute values still remained higher than the reference normal values $(-0.5 /+0.5$ $\mu \mathrm{mol} / \mathrm{l})$.

An unexpected increase in baseline blood oxygen tension $\left(\mathrm{PaO}_{2}+4.6 \mathrm{mmHg} ;+75 \%\right)$ was found at $\mathrm{T}_{12}$; interestingly, the improvement in $\mathrm{PaO}_{2}$ was not associated with a concomitant improvement in $\mathrm{PaCO}_{2}$

Furthermore, EAAs supplementation was associated with an increased physical autonomy at $\mathrm{T}_{12}$, resulting the baseline patients' daily physical activity improving by $80 \%$. However, even if significantly ameliorated, their physical activity still remained severely limited.

Moreover, at the end of the study, EAAs supplementation induced a significant increase in protein synthesis which changed from the basal value of $32.7 \mathrm{~g} / 1$ to $37 \mathrm{~g} / \mathrm{l}(+4.3 \mathrm{~g} / \mathrm{l})$.

Finally, both the cognitive dysfunction and particularly the negative perception of their health state were significantly ameliorated only in EAAs supplemented patients; as concerning the latter aspect, the SGRQ score proved sistematically improved from baseline (average drop of -2.7 points) even if it did not reach the four-point variation which is needed for claiming a substantial and effective benefit in patients' quality of life.

\section{Discussion}

\section{Baseline patient characteristics}

The present investigation proved that sarcopenia may be associated with exalted muscle anaerobic metabolism and reduced visceral protein synthesis in stable, severe COPD patients at rest. This biochemical condition is confirmed by the high plasma lactate levels and the low serum albumin concentration measured. Moreover, the presence of hyperlactatemia indirectly indicates that the muscle metabolism efficiency in producing energy was basally reduced.

These results are in line with those from previous studies that found a reduced muscle concentrations of energy substrates and cofactors [28] in COPD patients. Actually, several factors (such as, systemic inflammation; hypoxia, and muscle disuse) can cause an increased rate of muscle anaerobic metabolism in COPD [29].

In particular, it has been proved that inflammation is able to induce cytokine production
$[30,31]$ which can affect muscle glucose metabolism by reducing pyruvate oxidation [32]. Furthermore, hypoxia not only can affect glucose transport in axial skeletal muscles [33], but can also lead cell metabolism shifting from aerobic metabolism to the anaerobic one [34], while a low physical activity further impairs muscle aerobic metabolism [35]. The presence of this condition may be suggested in most disabled patients, such as those with severe limitations in washing, dressing, or walking less that 600 steps per daily.

In general terms, the consequences of an increased muscle anaerobic metabolism are deleterious for both the nutritional state and the exercise capacity. Firstly, lactate-induced cell acidosis leads to an exalted somatic and myofibrillar proteolysis [36]. Moreover, a cellular energy shortage can reduce both the muscle protein synthesis [37] and the physical activity as suggested by the negative correlation between plasma lactate and the number of steps performed by the patients in baseline conditions. Consequently, skeletal muscles of sarcopenic COPD patients are exposed to increased muscle catabolism continuously.

The reduction in serum albumin concentrations, which reflects a reduced liver synthesis rate of non-reactant proteins, may be regarded as secondary to a chronic inadequacy in protein caloric intake and/or the effect of systemic inflammation with a shift of liver protein synthesis from non-reactant proteins to the inflammatory ones [38]. It is possible that hypoxia contributed to reduce both FFM and albumin synthesis as it stimulates tumour necrosis factor alpha production $[30,31]$.

Patients of this study led a very sedentary lifestyle. Alterations in their body composition; ventilatory limitation [19]; muscle energy shortage; and muscle cell acidosis can likely represent factors which contributed to their impaired physical anatomy.

The present investigation also highlights the presence of a substantial basal cognitive dysfunction in the study population. This is in agreement with data from other important studies which demonstrated the presence of an higher rate of cognitive impairment [26] and a lower cognitive performance in standardised measurement overtime [25] among adults with COPD. It has also been suggested that this cognitive deterioration tends to reflect the severity of the COPD-induced pulmonary dysfunction [25]. Other studies linked the severity of the cognitive deterioration to the extent of lung function impairment in terms of $\mathrm{FEV}_{1}$ [39], and to brain perfusion abnormalities secondary to hypoxemia [40]. However, although we did not find any significant correlation between oxemia, lactate and cognitive test, the impaired blood gas pressures could have influenced the performance in cognitive test [41].

The clinical consequences of altered cognition can be relevant for COPD patients because cognitive dysfunction may further reduce patient adherence to therapeutic programs; enhance patients' disability, and decrease their quality of life [42]. 
Table 2. - Mean \pm SD and statistical analysis between placebo and EAA supplemented patients

\begin{tabular}{|c|c|c|c|c|c|c|c|c|c|}
\hline \multirow{2}{*}{$\begin{array}{l}\text { Variables } \\
\mathrm{PaCO}_{2}(\mathrm{mmHg})\end{array}$} & \multicolumn{4}{|c|}{ Placebo group } & \multicolumn{4}{|c|}{ EAA group } & \multirow{2}{*}{$\begin{array}{l}\text { Interaction } \\
\mathrm{p}=0.77\end{array}$} \\
\hline & $\begin{array}{l}\text { T0 } \\
\text { T4 } \\
\text { T12 }\end{array}$ & $\begin{array}{c}46.28 \pm 7.6 \\
46.21 \pm 3.88 \\
45.47 \pm 4.87\end{array}$ & $\begin{array}{l}\mathrm{T} 4 \text { vs } \mathrm{T} \\
\mathrm{ns}\end{array}$ & $\begin{array}{c}12 \text { vs T0 } \\
\text { ns }\end{array}$ & $\begin{array}{c}\text { T0 } \\
\text { T4 } \\
\text { T12 }\end{array}$ & $\begin{array}{c}45.32 \pm 6 \\
46.32 \pm 5.22 \\
46 \pm 3.74\end{array}$ & $\begin{array}{c}\mathrm{T} 4 \text { vs } \mathrm{T} 0 \\
\mathrm{~ns}\end{array}$ & $\begin{array}{c}\mathrm{T} 12 \text { vs } \mathrm{T} 0 \\
\mathrm{p}=0.46\end{array}$ & \\
\hline $\mathrm{PaO}_{2}(\mathrm{mmHg})$ & $\begin{array}{c}\text { T0 } \\
\text { T4 } \\
\text { T12 }\end{array}$ & $\begin{array}{l}60.15 \pm 4.88 \\
58.12 \pm 4.58 \\
57.14 \pm 4.14\end{array}$ & ns & ns & $\begin{array}{c}\text { T0 } \\
\text { T4 } \\
\text { T12 }\end{array}$ & $\begin{array}{c}61.56 \pm 8.5 \\
62.20 \pm 6.28 \\
66.31 \pm 5.89\end{array}$ & ns & $\mathrm{p}=0.01$ & $\mathrm{p}=0.039$ \\
\hline $\mathrm{sO}_{2}$ & $\begin{array}{c}\text { T0 } \\
\text { T4 } \\
\text { T12 }\end{array}$ & $\begin{array}{c}94.32 \pm 0.96 \\
93.98 \pm 1.71 \\
94 \pm 1.73\end{array}$ & ns & ns & $\begin{array}{c}\text { T0 } \\
\text { T4 } \\
\text { T12 }\end{array}$ & $\begin{array}{c}94.6 \pm 1.86 \\
92.75 \pm 2.76 \\
94 \pm 2.42\end{array}$ & ns & $\mathrm{p}=0.75$ & $\mathrm{p}=0.04$ \\
\hline $\mathrm{FEV}_{1}(1 / \mathrm{sec})$ & $\begin{array}{c}\text { T0 } \\
\text { T4 } \\
\text { T12 }\end{array}$ & $\begin{array}{l}0.84 \pm 0.15 \\
0.78 \pm 0.16 \\
0.75 \pm 0.15\end{array}$ & ns & ns & $\begin{array}{c}\text { T0 } \\
\text { T4 } \\
\text { T12 }\end{array}$ & $\begin{array}{l}0.90 \pm 0.22 \\
0.90 \pm 0.22 \\
0.86 \pm 0.16\end{array}$ & ns & $\mathrm{p}=0.46$ & $\mathrm{p}=0.58$ \\
\hline FEV\% (\%) & $\begin{array}{c}\text { T0 } \\
\text { T4 } \\
\text { T12 }\end{array}$ & $\begin{array}{c}38 \pm 11.49 \\
37.61 \pm 12.9 \\
36.13 \pm 10.33\end{array}$ & ns & $\mathrm{ns}$ & $\begin{array}{c}\text { T0 } \\
\text { T4 } \\
\text { T12 }\end{array}$ & $\begin{array}{c}39.62 \pm 7.35 \\
39.5 \pm 7.20 \\
39.19 \pm 7.5\end{array}$ & ns & $\mathrm{p}=0.7$ & $\mathrm{p}=0.89$ \\
\hline Lactate $(\mu \mathrm{mol} / \mathrm{l})$ & $\begin{array}{c}\text { T0 } \\
\text { T4 } \\
\text { T12 }\end{array}$ & $\begin{array}{c}1.73 \pm 0.27 \\
1.8 \pm 0.35 \\
1.95 \pm 0.36\end{array}$ & ns & ns & $\begin{array}{c}\mathrm{T} 1 \\
\mathrm{~T} 4 \\
\mathrm{~T} 12\end{array}$ & $\begin{array}{c}1.65 \pm 0.70 \\
1.43 \pm 0.30 \\
1.3 \pm 0.57\end{array}$ & ns & $\mathrm{p}=0.023$ & $\mathrm{p}=0.07$ \\
\hline FFM (Kg) & $\begin{array}{c}\text { T0 } \\
\text { T4 } \\
\text { T12 }\end{array}$ & $\begin{array}{c}39.86 \pm 4.82 \\
39.95 \pm 3 \\
39.73 \pm 2.78\end{array}$ & ns & ns & $\begin{array}{c}\text { T0 } \\
\text { T4 } \\
\text { T12 }\end{array}$ & $\begin{array}{c}40.41 \pm 4 \\
41.56 \pm 4.51 \\
44 \pm 4.53\end{array}$ & ns & $\mathrm{p}=0.05$ & $\mathrm{p}=0.05$ \\
\hline $\mathrm{BW}(\mathrm{Kg})$ & $\begin{array}{c}\text { T0 } \\
\text { T4 } \\
\text { T12 }\end{array}$ & $\begin{array}{c}54.38 \pm 6.95 \\
54 \pm 6.82 \\
53.31 \pm 5.77\end{array}$ & ns & ns & $\begin{array}{c}\text { T0 } \\
\text { T4 } \\
\text { T12 }\end{array}$ & $\begin{array}{c}53.47 \pm 6.53 \\
55.4 \pm 8.44 \\
59 \pm 10\end{array}$ & ns & $\mathrm{p}=0.002$ & $\mathrm{p}=0.006$ \\
\hline LBMI $\left(\mathrm{Kg} / \mathrm{m}^{2}\right)$ & $\begin{array}{c}\text { T0 } \\
\text { T4 } \\
\text { T12 }\end{array}$ & $\begin{array}{c}14.91 \pm 2 \\
14.97 \pm 1.73 \\
14.89 \pm 1.63\end{array}$ & ns & ns & $\begin{array}{c}\text { T0 } \\
\text { T4 } \\
\text { T12 }\end{array}$ & $\begin{array}{c}15.34 \pm 2 \\
15.7 \pm 1.51 \\
16.68 \pm 2\end{array}$ & ns & $\mathrm{p}=0.07$ & $\mathrm{p}=0.09$ \\
\hline BMI $\left(\mathrm{Kg} / \mathrm{m}^{2}\right)$ & $\begin{array}{c}\text { T0 } \\
\text { T4 } \\
\text { T12 }\end{array}$ & $\begin{array}{c}20.21 \pm 1.80 \\
20 \pm 1.65 \\
19.9 \pm 1.69\end{array}$ & ns & ns & $\begin{array}{c}\text { T0 } \\
\text { T4 } \\
\text { T12 }\end{array}$ & $\begin{array}{l}20.16 \pm 1.43 \\
20.82 \pm 2.34 \\
22.26 \pm 2.68\end{array}$ & ns & $\mathrm{p}=0.002$ & $\mathrm{p}=0.006$ \\
\hline Steps $\left(n^{\circ}\right)$ & $\begin{array}{c}\text { T0 } \\
\text { T4 } \\
\text { T12 }\end{array}$ & $\begin{array}{l}609.81 \pm 454.72 \\
651.94 \pm 557.88 \\
562.88 \pm 601.87\end{array}$ & ns & ns & $\begin{array}{c}\text { T0 } \\
\text { T4 } \\
\text { T12 }\end{array}$ & $\begin{array}{c}638.8 \pm 661.8 \\
880.20 \pm 836.60 \\
1140.53 \pm 524.39\end{array}$ & ns & $\mathrm{p}=0.01$ & $\mathrm{p}=0.0027$ \\
\hline Serum total proteins $(\mathrm{g} / \mathrm{l})$ & $\begin{array}{c}\text { T0 } \\
\text { T4 } \\
\text { T12 }\end{array}$ & $\begin{array}{l}61.57 \pm 5.15 \\
60.35 \pm 5.17 \\
60.94 \pm 5.12\end{array}$ & ns & ns & $\begin{array}{c}\text { T0 } \\
\text { T4 } \\
\text { T12 }\end{array}$ & $\begin{array}{c}62.20 \pm 2.66 \\
63.83 \pm 3.96 \\
65 \pm 3.57\end{array}$ & ns & $\mathrm{p}=0.041$ & $\mathrm{p}=0.12$ \\
\hline Serum albumin $(\mathrm{g} / \mathrm{l})$ & $\begin{array}{c}\text { T0 } \\
\text { T4 } \\
\text { T12 }\end{array}$ & $\begin{array}{l}33.16 \pm 2.71 \\
32.49 \pm 3.43 \\
33.28 \pm 4.39\end{array}$ & ns & ns & $\begin{array}{c}\text { T0 } \\
\text { T4 } \\
\text { T12 }\end{array}$ & $\begin{array}{l}32.94 \pm 3.67 \\
35.14 \pm 3.51 \\
37.22 \pm 2.86\end{array}$ & $\mathrm{p}=0.001$ & $\mathrm{p}=0.001$ & $\mathrm{p}<.001$ \\
\hline MMT (score) & $\begin{array}{c}\text { T0 } \\
\text { T4 } \\
\text { T12 }\end{array}$ & $\begin{array}{l}20.19 \pm 3.52 \\
19.62 \pm 3.59 \\
19.44 \pm 3.68\end{array}$ & ns & ns & $\begin{array}{c}\text { T0 } \\
\text { T4 } \\
\text { T12 }\end{array}$ & $\begin{array}{c}19.13 \pm 4.6 \\
19 \pm 3.9 \\
20.75 \pm 3.92\end{array}$ & ns & $\mathrm{p}=0.011$ & $\mathrm{p}=0.011$ \\
\hline SGRQ (score) & $\begin{array}{c}\text { T0 } \\
\text { T4 } \\
\text { T12 }\end{array}$ & $\begin{array}{c}71.44 \pm 6.98 \\
- \\
72.81 \pm 7\end{array}$ & ns & ns & $\begin{array}{c}\text { T0 } \\
\text { T4 } \\
\text { T12 }\end{array}$ & $\begin{array}{c}72.25 \pm 8.52 \\
- \\
69.56 \pm 9.41\end{array}$ & $\mathrm{p}=0.01$ & - & $\mathrm{p}<0.001$ \\
\hline
\end{tabular}

Data is expressed as main \pm standard deviation.

Statistical analysis: Anova test.

T0: baseline; T4: after 1 months; T12: after 3 months.

EAA group: essential amino acid supplemented group.

$\mathrm{PaO}_{2}$ : partial pressure of oxygen; $\mathrm{PaCO}_{2}$ : Partial pressure of carbon dioxide; $\mathrm{sO}_{2}$ : oxygen saturation; $\mathrm{FEV}_{1}$ : forced expiratory volume1; FVC: forced vital capacity; FFM: fat-free mass; BW: body weight; LBMI: Lean Body Mass Index; BMI: Body Mass Index; MMT: Mini Mental State Examination test; SGRQ: St.George's Respiratory Questionnaire. 

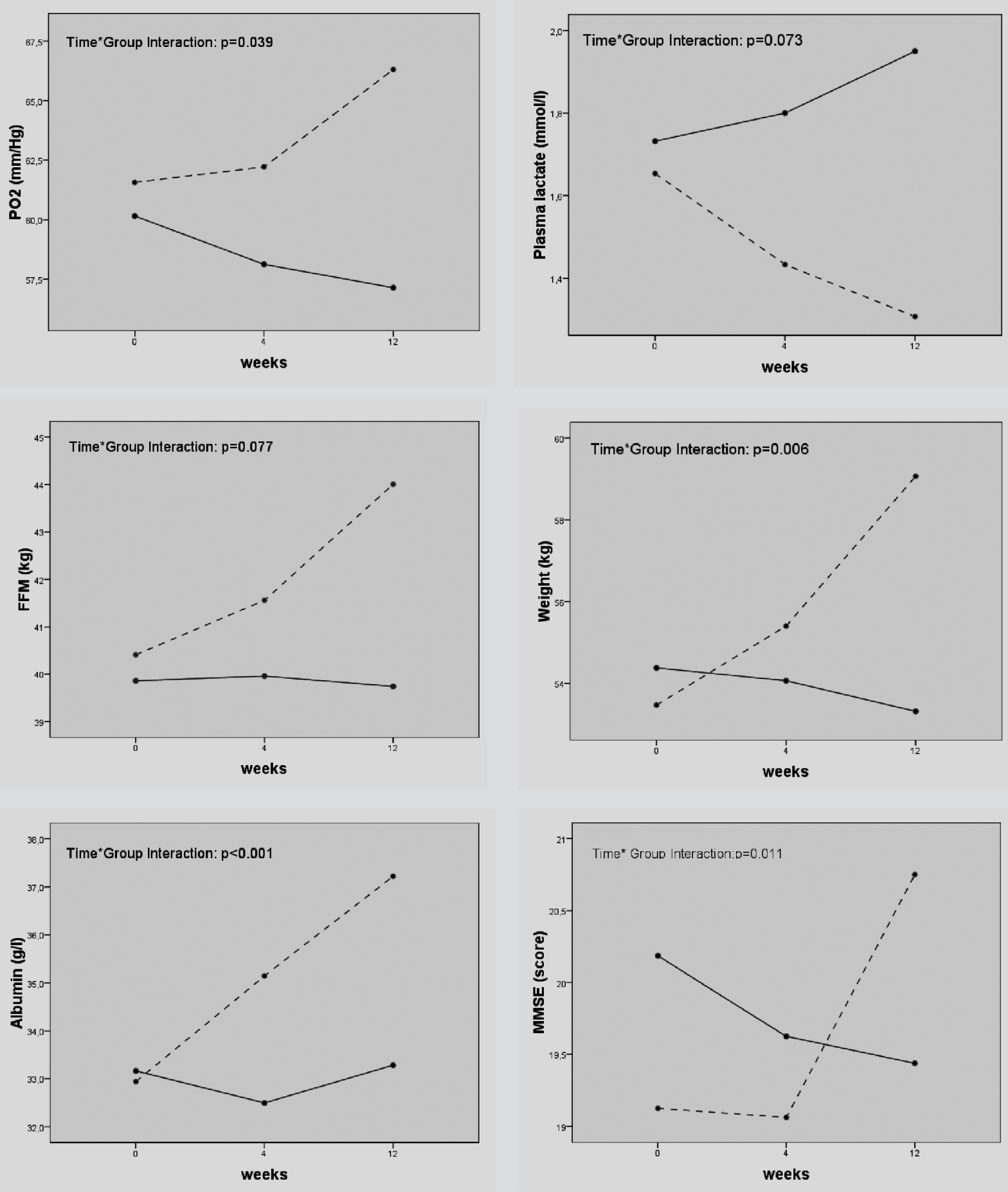

Fig. 1. - Trends over time of blood oxygen tension $\left(\mathrm{PaO}_{2}\right)$, plasma lactate concentration, lean body mass (FFM), body weight, serum albumin concentration, neuropsychological test (MMSE) variables: Placebo Group (-) vs EAAs (Aminotrophic) treated Group (---).

\section{Effects of EAAs on patient variables}

\section{EAAs AND BODY COMPOSITION}

The $3.6 \mathrm{Kg}$ improvement in FFM following EAA supplementation is impressive when considering the $1.1 \mathrm{Kg}$ gain of FFM obtained after a 8week period of pulmonary rehabilitation [12].

It is interesting to note that the $10 \%$ increase in FFM observed in the present study after EAAs supplementation is close to the $11.8 \%$ increase in skeletal mass obtained in patients suffering from COPD after a two-month supplementation with the same formula used in the current investigation [43].

Nevertheless, the increase obtained in body weight $(+6 \mathrm{Kg})$ in the present study is higher than that obtained in previous investigations showing a weight stability after a nutritional supplementation $(+570 \mathrm{Kcal}$ from carbohydrates; via $800 \mathrm{mg} /$ day of 
megestrol acetate for eight weeks) combined with pulmonary rehabilitation [44]. This difference can likely be related to the characteristics of the substrate used because megestrol is known to mainly increase fat mass (FM) and not muscle tissue, being mechanisms underlining the effects of EAAs both direct and indirect.

In fact, EAAs directly stimulate protein synthesis [45] and inhibit proteolysis [46] in several tissue including skeletal muscle and the liver. The peculiar activity of EAAs in these districts may explain the amelioration of both FFM and albumin synthesis. To note that EAA-promoted protein synthesis is independent of insulin [21]: this feature represents a relevant aspect particularly for those COPD patients with insulin-resistance and following a long-term corticosteroid therapy, and/or during acute exacerbations. In addition, the stimulation of protein anabolism by EAAs could benefit sarcopenic patients with diminished circulating levels of anabolic hormones including testosterone, growth hormone and insulin-like growth factor (IGF-1) [47].

EAAs may indirectly exert their activity on muscle and liver protein synthesis by augmented the biological activity of IGF-1 [24].

\section{EAAS AND MUSCLE METABOLISM}

The study proved that EAAs supplementation, but not placebo, is associated with a significant reduction in plasma lactate (figure 1).

The improvement in lactate formation could be due to the effects of EAAs on muscle metabolism as EAAs can stimulate the aerobic energy-producing pathway [37] both directly by entering the aerobic cycle as alternative substrate [37], and indirectly by shifting lactate pyruvate reaction to the right [37]. In this way EAAs could overcome the block of glucose aerobic oxidation caused by proinflammatory cytokines via the aerobic metabolism re-activation [32].

\section{EAAS AND DAILY PHYSICAL ACTIVITY}

Data from the present study also proved the progressive improvement in daily physical activity in EAAs-supplemented patients, even though their physical autonomy remained greatly limited, being the total steps daily performed by supplemented EAAs about 1085 after a three-month supplementation.

The improvement in patients' walking capacity may be related to several factors including the improvement in their nutritional state, aerobic metabolism, body anabolism (albumin). All these factors can also ameliorate patients' motivation to physical activity. The different mechanisms contributing to improve physical capacity may likely account for the absence of any significant relationship between lactatemia and physical activity that we found at the patients' randomisation time. An important factor that could improve the physical activity might be the increase in muscle strength, not measured in the study. It is reasonable to pre- sume the amelioration of muscle strength as patients ameliorated both their FFM and aerobic metabolism.

\section{EAAS AND BLOOD OXYGEN TENSION}

The gradual improvement in $\mathrm{PaO}_{2}$ following EAAs was unexpected. A speculative explanation is that the improvement in $\mathrm{PaO}_{2}$ could be due to EAA influence on cardiac function [48] which can ameliorate pulmonary blood flux/distribution. A better oxemia may be crucial for COPD evolution as it should reduce the stimulus to cytokine production and decrease the release of both interleukin 1 and tumour necrosis factor alpha in human alveolar macrophages [49]. Reduction of chronic hypoxemia may also contribute to increase FFM and body weight in the patients of the study.

\section{EAAS AND COGNITION AND HEALTH STATUS}

The increase in blood oxygen tension may enhance brain perfusion that on the contrary is reduced by chronic hypoxia [41]; brain hypoperfusion is also hypothesised to affect cognitive performance in these patients [40].

Moreover, we tend to emphasize that the EAAs-associated improvement in cognition should be related to both the oxemia amelioration and the increased availability of neurotransmitters' amino acids precursors in the brain. In fact, amino acids used in the present study contain several precursors of brain neurotransmitters that play an important role in cognition, motor function and mood [50], such as: brain norepinephrine, dopamine, epinephrine transmitters derived from tyrosine; serotonine from tryptophan; acetylcholine from methionine; histamine from histidine. It is important to note that the brain of hypoxic COPD subjects need an increased amount of neurotransmitter precursors as hypoxia facilitates per se the circulating levels of catecholamines through mechanisms involving the increased synthesis and/or release [51, 52] of acetylcholine [53].

The improvement in the patient perception of health status may be a consequence of the increased body weight and FFM; body anabolic orientation (total protein and albumin synthesis); higher oxemia, and reduction in cognitive impairment.

The amelioration of cognition and health status could have relevant clinical consequences which include improvements in patient adherence to treatment and maintenance of their independence over time [25].

\section{Clinical perspectives}

Results of the present study accord with data from two recent studies carried out on cachectic COPD [54] and on muscle-depleted patients with chronic heart failure [55] which were both supplemented with the same aminoacid formula (at the same dose) as that used in the present investigation. 
The study suggests that EAAs might results particularly useful in those COPD patients who cannot undergo to rehabilitation for any reason, or cannot perform any intensive physical training due to the presence of severe comorbidities, or to the subject subject's frailty being too severe.

It is also presumable that EAAs may act synergistically with rehabilitation and optimise corresponding outcomes in terms of the recover of nutritional status, cognitive dysfunction and quality of life in severe COPD patients with sarcopenia.

\section{Limitations of the study}

We are aware that the present study has some limitations. First, the small number of the patients' sample precluded any conclusion on possible gender-related difference in the results.

Second, patients were not investigated in terms of their daily nutritional intake, and this particular aspect might be relevant when evaluating the possible role of EAA supplementation in affecting protein caloric intake effectively.

Finally, patients were not followed after EAA discontinuation and then we can not draw any conclusion on maintenance of changes overtime. Conversely, the study was planned only with the aim of investigating whether or not EAAs could have any impact on sarcopenic condition of severe COPD patients.

In conclusion, even if further larger investigations are needed in the future to face specifically all these aspects and validate present data, the actual results from the present study emphasisethat a three-month EAAs supplementation in sarcopenic patients with severe COPD can lead to a substantial improvements in the patient's body weight and body composition; peripheral muscle anaerobic metabolism; oxemia; daily physical activity; cognitive function, and perception of their own health status.

\section{References}

1. Wilson DO, Rogers RM, Wright EC, Anthonisen NR. Body weight in chronic obstructive pulmonary disease. The National Institutes of Health Intermittent PositivePressure Breathing Trial. Am Rev Respir Dis 1989; 139: 1435-8.

2. Engelen MP, Schols AM, Baken WC, Wesseling GJ, Wouters EF. Nutritional depletion in relation to respiratory and peripheral skeletal muscle function in out-patients with COPD. Eur Respir J 1994; 7: 1793-7.

3. Vandenbergh E, Van de Woestijne KP, Gyselen A. Weight changes in the terminal stages of chronic obstructive pulmonary disease. Relation to respiratory function and prognosis. Am Rev Respir Dis 1967; 95: 556-66.

4. Congleton J. The pulmonary cachexia syndrome: aspects of energy balance. Proc Nutr Soc 1999; 58: 321-8.

5. Schols AM, Soeters PB, Dingemans AM, Mostert R, Frantzen PJ, Wouters EF. Prevalence and characteristics of nutritional depletion in patients with stable COPD eligible for pulmonary rehabilitation. Am Rev Respir Dis 1993; 147: 1151-6.
6. Schols AM, Mostert R, Soeters PB, Wouters EF. Body composition and exercise performance in patients with chronic obstructive pulmonary disease. Thorax 1991; 46: 695-9.

7. Gosselink R, Troosters T, Decramer M. Peripheral muscle weakness contributes to exercise limitation in COPD. Am J Respir Crit Care Med 1996; 153: 976-80.

8. Hamilton AL, Killian KJ, Summers E, Jones NL. Muscle strength, symptom intensity, and exercise capacity in patients with cardiorespiratory disorders. Am J Respir Crit Care Med 1995; 152 (6 Pt 1): 2021-31.

9. Foley RJ, ZuWallack R. The impact of nutritional depletion in chronic obstructive pulmonary disease. $J$ Cardiopulm Rehabil 2001; 21: 288-95.

10. Schols AM, Broekhuizen R, Weling-Scheepers CA, Wouters EF. Body composition and mortality in chronic obstructive pulmonary disease. Am J Clin Nutr 2005; 82: 53-9.

11. Schols AM, Slangen J, Volovics L, Wouters EF. Weight loss is a reversible factor in the prognosis of chronic obstructive pulmonary disease. Am J Respir Crit Care Med 1998; 157 (6 Pt 1): 1791-7.

12. Creutzberg EC, Wouters EF, Mostert R, Weling-Scheepers CA, Schols AM. Efficacy of nutritional supplementation therapy in depleted patients with chronic obstructive pulmonary disease. Nutrition 2003; 19: 120-7.

13. De Boer WI. Cytokines and therapy in COPD: a promising combination? Chest 2002; 121 (5 Suppl): 209S-218S.

14. Burdet L, de Muralt B, Schutz Y, Pichard C, Fitting JW. Administration of growth hormone to underweight patients with chronic obstructive pulmonary disease. A prospective, randomized, controlled study. Am J Respir Crit Care Med 1997; 156: 1800-6.

15. Schols AM, Soeters PB, Mostert R, Pluymers RJ, Wouters EF. Physiologic effects of nutritional support and anabolic steroids in patients with chronic obstructive pulmonary disease. A placebo-controlled randomized trial. Am J Respir Crit Care Med 1995; 152 (4 Pt 1): 1268-74.

16. Ferreira IM, Verreschi IT, Nery LE, et al. The influence of 6 months of oral anabolic steroids on body mass and respiratory muscles in undernourished COPD patients. Chest 1998; 114: 19-28.

17. Yeh SS, DeGuzman B, Kramer T; M012 Study Group. Reversal of COPD-associated weight loss using the anabolic agent oxandrolone. Chest 2002; 122: 421-8.

18. Franssen FM, Broekhuizen R, Janssen PP, Wouters EF, Schols AM. Effects of whole-body exercise training on body composition and functional capacity in normalweight patients with COPD. Chest 2004; 125: 2021-8.

19. Palange P, Forte S, Onorati P, Paravati V, Manfredi F, Serra P, Carlone S. Effect of reduced body weight on muscle aerobic capacity in patients with COPD. Chest 1998; 114: 12-8.

20. Gosker HR, Engelen MP, van Mameren H, et al. Muscle fiber type IIX atrophy is involved in the loss of fatfree mass in chronic obstructive pulmonary disease. $\mathrm{Am}$ J Clin Nutr 2002; 76: 113-9.

21. Volpi E, Ferrando AA, Yeckel CW, Tipton KD, Wolfe RR. Exogenous amino acids stimulate net muscle protein synthesis in the elderly. J Clin Invest 1998; 101: 2000-7.

22. Layman DK. Role of leucine in protein metabolism during exercise and recovery. Can J Appl Physiol 2002; 27: 646-63.

23. Iritani N, Sugimoto T, Fukuda H, Komiya M, Ikeda H. Dietary soybean protein increases insulin receptor gene expression in Wistar fatty rats when dietary polyunsaturated fatty acid level is low. J Nutr 1997; 127: 1077-83.

24. Jousse C, Bruhat A, Ferrara M, Fafournoux P. Physiological concentration of amino acids regulates insulin- 
like-growth-factor-binding protein 1 expression. Biochem $J$ 1998; 334 (Pt 1): 147-53.

25. Hung WW, Wisnivesky JP, Siu AL, Ross JS. Cognitive decline among patients with chronic obstructive pulmonary disease. Am J Respir Crit Care Med 2009; 180: 134-7.

26. Isoaho R, Puolijoki H, Huhti E, Laippala P, Kivelä SL. Chronic obstructive pulmonary disease and cognitive impairment in the elderly. Int Psychogeriatr 1996; 8: 113-25.

27. Fernstrom ID, Faller DV. Neutral amino acids in the brain: changes in response to food ingestion. $\mathrm{J} \mathrm{Neu}$ rochem 1987; 72: 897-901.

28. Pouw EM, Schols AM, van der Vusse GJ, Wouters EF. Elevated inosine monophosphate levels in resting muscle of patients with stable chronic obstructive pulmonary disease. Am J Respir Crit Care Med 1998; 157: 453-7.

29. Gosker HR, Wouters EF, van der Vusse GJ, Schols AM. Skeletal muscle dysfunction in chronic obstructive pulmonary disease and chronic heart failure: underlying mechanisms and therapy perspectives. Am J Clin Nutr 2000; 71: 1033-47.

30. Schols AM, Buurman WA, Staal van den Brekel AJ, Dentener MA, Wouters EF. Evidence for a relation between metabolic derangements and increased levels of inflammatory mediators in a subgroup of patients with chronic obstructive pulmonary disease. Thorax 1996; 51: 819-24.

31. Pitsiou G, Kyriazis G, Hatzizisi O, Argyropoulou P, Mavrofridis E, Patakas D. Tumor necrosis factor-alpha serum levels, weight loss and tissue oxygenation in chronic obstructive pulmonary disease. Respir Med 2002; 96: 594-8.

32. Vary TC, O'Neill P, Cooney RN, Maish G 3rd, Shumate M. Chronic infusion of interleukin 1 induces hyperlactatemia and altered regulation of lactate metabolism in skeletal muscle. J Parenter Enteral Nutr 1999; 23: 213-7.

33. Xia Y, Warshaw JB, Haddad GG. Effect of chronic hypoxia on glucose transporters in heart and skeletal muscle of immature and adult rats. Am J Physiol 1997; 273 (5 Pt 2): R1734-41.

34. Pastoris O, Dossena M, Foppa P, et al. Modifications by chronic intermittent hypoxia and drug treatment on skeletal muscle metabolism. Neurochem Res 1995; 20: 143-50.

35. Terjung RL, Dudley GA, Meyer RA. Metabolic and circulatory limitations to muscular performance at the organ level. J Exp Biol 1985; 115: 307-18.

36. Mitch WE, Goldberg AL. Mechanisms of muscle wasting. The role of the ubiquitin-proteasome pathway. $N$ Engl J Med 1996; 335 (25): 1897-905.

37. Lehninger AL, Nelson DL, Cox MM. In: Zanichelli, editor. Principi di Biochimica 2nd ed.: 1994.

38. Desborough JP. The stress response to trauma and surgery. Br J Anaesth 2000; 85: 109-17.

39. Richards M, Strachan D, Hardy R, Kuh D, Wadsworth M. Lung function and cognitive ability in a longitudinal birth cohort study. Psychosom Med 2005; 67: 602-8.

40. Ortapamuk H, Naldoken S. Brain perfusion abnormalities in chronic obstructive pulmonary disease: compar- ison with cognitive impairment. Ann Nucl Med 2006; 20: 99-106.

41. Incalzi RA, Gemma A, Marra C, Muzzolon R, Capparella O, Carbonin P. Chronic obstructive pulmonary disease. An original model of cognitive decline. Am Rev Respir Dis 1993; 148: 418-24.

42. Tabert MH, Albert SM, Borukhova-Milov L, et al. Functional deficits in patients with mild cognitive impairment: prediction of AD. Neurology 2002; 12; 58: 758-64.

43. Steiner MC, Barton RL, Singh SJ, Morgan MD. Nutritional enhancement of exercise performance in chronic obstructive pulmonary disease: a randomised controlled trial. Thorax 2003; 58: 745-51.

44. Weisberg J, Wanger J, Olson J, et al. Megestrol acetate stimulates weight gain and ventilation in underweight COPD patients. Chest 2002; 121: 1070-8.

45. Kimball SR, Fabian JR, Pavitt GD, Hinnebusch AG, Jefferson LS. Regulation of guanine nucleotide exchange through phosphorylation of eukaryotic initiation factor eIF2alpha. Role of the alpha- and delta-subunits of eiF2b. J Biol Chem 1998; 273: 12841-5.

46. Wang X, Campbell LE, Miller CM, Proud CG. Amino acid availability regulates p70 S6 kinase and multiple translation factors. Biochem J 1998; 334: 261-7.

47. Creutzberg EC, Casaburi R. Endocrinological disturbances in chronic obstructive pulmonary disease. Eur Respir J Suppl 2003; 46: 76s-80s.

48. Scognamiglio R, Negut C, Palisi M, Dioguardi FS, Coccato M, Iliceto S. Effects of oral amino acid supplements on cardiac function and remodeling in patients with type 2 diabetes with mild-to-moderate left ventricular dysfunction. Am J Cardiol 2008; 101: 111E-115E.

49. Takabatake N, Nakamura H, Abe S, et al. The relationship between chronic hypoxemia and activation of the tumor necrosis factor-alpha system in patients with chronic obstructive pulmonary disease. Am J Respir Crit Care Med 2000; 161 (4 Pt 1): 1179-84.

50. Clarke DD, Sokoloff L. Circulation and energy metabolism of the brain. In: Sigel GJ, Agranoff BW, Albers RW, Fisher SK, Uhler MD, editors. Basic Neurochemistry. Philadelphia: Lippincott-Raven; 1998: 637-69.

51. Fletcher EC, Lesske J, Behm R, Miller CC 3rd, Stauss $\mathrm{H}$, Unger T. Carotid chemoreceptors, systemic blood pressure, and chronic episodic hypoxia mimicking sleep apnea. J Appl Physiol 1992; 72: 1978-84.

52. Ziegler MG, Nelesen R, Mills P, Ancoli-Israel S, Kennedy B, Dimsdale JE. Sleep apnea, norepinephrine-release rate, and daytime hypertension. Sleep 1997; 20: 224-31.

53. Kim DK, Natarajan N, Prabhakar NR, Kumar GK. Facilitation of dopamine and acetylcholine release by intermittent hypoxia in PC12 cells: involvement of calcium and reactive oxygen species. J Appl Physiol 2004; 96: 1206-15.

54. Baldi S, Aquilani R, Poggi P, Venegoni E. Fat-free mass change after nutritional rehabilitation in weight loosing COPD: role of insulin, C-reactive protein and tissue hypoxia. Int J COPD 2009 submitted.

55. Aquilani R, Opasich C, Gualco A, et al. Adequate energy-protein intake is not enough to improve nutritional and metabolic status in muscle-depleted patients with chronic heart failure. Eur J Heart Fail 2008; 10: 1127-35. 